\title{
POLITICAL UNION? \\ SOME CRITICAL REFLECTIONS
}

\author{
OTMAR ISSING*
}

Fecha de recepción: 10 de noviembre de 2012.

Fecha de aceptación: 19 de diciembre de 2012.

This conference brings together an impressive number of eminent politicians, outstanding representatives from business, public administration and academia. Notwithstanding nuances there seems to be a broad consensus that the crisis has demonstrated not only that we need more Europe, but also - having read many contributions - how this «more Europe» should be realized.

Bearing in mind the atrocities of two World Wars, the separation of Europe by the iron curtain, the challenge stemming from globalisation and a rapidly changing world who would not support the project of a strong and prosperous Europe to guarantee peace in this sphere and to assert, if not enhance its position in the world. However, agreement on the goal does not necessarily imply agreement on the way and the tools by which this end can be achieved.

While the positions presented at this conference and at many other occasions have been straightforward and firm, my position is much more cautious. I will, in fact, mainly raise a number of questions.

"If the Euro fails, Europe will fail», is Chancellor Merkel's dictum. I am critical on this. The Euro, not to mention Europe is not at stake. What is at stake is the euro zone, and by that I mean the composition of the euro zone rather than the euro zone itself.

A popular argument is that the crisis confronts «Europe» - or rather EMU - with two alternatives. Either political integration

* Contribution to the Meeting of the Council for the Future of Europe Berlin, 30 October 2012. 
is strengthened with the «finalité» of political union or monetary union is doomed to collapse.

Is this not turning upside down the initial idea that a flourishing monetary union would function as a pacemaker for political union? Remember J. Rueff's slogan (1950): «L'Europe se féra par la monnaie ou ne se féra pas.» The former German president von Weizsäcker once claimed that it is only via a single currency that we would achieve a common foreign policy. And he remarked that this avenue would be anything but cheap. At least on that point he was right. Yet, has the intensified effort of keeping EMU together brought us nearer to a common foreign policy?

Isn't, indeed, the opposite true that the crisis has sparked resentments in almost all countries -independent of being receivers or lenders of financial aid - resentments which we hoped had disappeared more than 60 years after World War II? With this experience in mind is the conclusion from the crisis of EMU, integration did not go far enough, really justified? Politics made a courageous decision to start monetary union on 1 January 1999, and with such a heterogeneous group against strong warnings. This risky approach was later continued. Fundamental principles on which EMU was based were violated time and again. I mention only the Stability and Growth pact, and in first place the no-bailout principle. As sovereign states did not deliver on their commitments, sovereignty has to be ended now? - a hardly convincing argument.

And isn't the idea that intermediate steps like the introduction of a kind of European financial authority - e.g. in form of a European finance minister or a Commissioner with far reaching competencies - make crisis management much more efficient and conducive for further political integration a dangerous illusion? Authority on taxes and public expenditure is a fundamental prerequisite of parliament and the sovereign in a democracy. In short: All measures that implicitly pre-empt the establishment of political union in this field are inconsistent and dangerous. They imply huge financial risks for some member countries and could not only undermine honourable efforts in the direction of political union, but also destroy the fundament on which such a process finally rests, namely the identification of the people with the European idea. 
Another topsy-turvy case can be observed in the argumentation of Jürgen Habermas. I quote him because he is by many regarded as an undisputable authority (see J. Habermas, Europe - The Faltering Project). He complains that an «elitist approach» was so far applied. "The liberal economic forces driving this mutually beneficial dynamics were sufficiently strong to ensure the construction of the requisite institutions "from above", through an agreement between the political elites of the member states» (p. 80). One could dispute to what extent this is true -a referendum e.g. in France on the Maastricht Treaty, but not in Germany- however in his anti-market resentment he ignores that it was exactly the concept based on competition within a single market and the idea of the euro as a stable currency which made the project popular. This popularity has declined to the lowest level in the context of the crisis. And in such an environment, is the Habermas idea of a «bottom-up» approach to political integration in essence not the extreme of an «elitist» programme?

There is a fundamental flaw in the position of Habermas - and many others. The attractiveness of «Europe» to a high degree rests on its economic success, on growth and employment. This is also the indispensable basis for Europe's political role in the world. The crisis has brought new, convincing evidence for the observation that those countries perform best that dispose of a higher degree of flexibility in labour markets, less protective regimes for business and professions, and modest taxation. Such a regime is denounced by Habermas and followers as «neo-liberalist» although no country in reality comes close to this.

The famous Blair-Schröder paper of 1999 has asked for a benchmarking based on best practice. The Lisbon agenda, e.g. with the goal to make the EU «the most competitive and dynamic knowledge-based economy in the world capable of sustainable economic growth with more and better jobs and greater social cohesion», was doomed to fail from the beginning. Is this failure an argument to try it again with a «more Europe» approach? Is it an argument for European economic governance, harmonisation and centralisation of policies? This is the widespread belief, it is also the message of most papers presented at this conference. 
Because of time constraint I refer to only one example. President Barroso in his "State of the Union 2012 Address» (Strasbourg, 12 September 2012) e.g. claimed: «A true political European Union means we must concentrate European action on the real issues that matter and must be dealt with at the European level» (p. 10). And: «To deliver lasting results, we need to develop a fully equipped Community economic governance together with a genuine, credible Community fiscal capacity» (p. 8).

In short - the Commission asks for more competence, more power. This certainly is anything but surprising. Yet, is harmonisation of taxes, a larger budget, a new industrial policy the avenue for higher growth, more and better jobs? Remember, it was a purely national initiative when $\mathrm{G}$. Schröder implemented the Agenda 2010 - a major contribution to Germany`s economic performance.

Economic theory and historical experience tell a different story. In the tradition of the seminal work by Douglas North numerous other studies have demonstrated that competition between states and regions laid the ground for progress and growth. This was the basis for Europe becoming the most dynamic, prosperous region in the world. True, it was also a time of wars. However, is centralisation a guarantee for safeguarding peace?

The fundamental problem in many approaches is that they start from and are based on a mechanistic approach to economic policy. Harmonisation and coordination, centralisation of decisions are seen as the tool, the panacea to all kinds of problems. Should one not start from the experience that appropriate institutions, private property rights and competition, a growth friendly tax system and solid fiscal policies are the basis for economic success? (see e.g. the recent work by Daron Acemoglu and James Robinson: Why Nations Fail, New York 2012). How would a European concept look like if one would not indulge in a seemingly ideological concept but develop a framework which would really help to turn Europe into a dynamic and prosperous region?

In contrast to this challenge a constructivist approach dominates representing a pretense of knowledge which Hayek has unmasked as a recipe for constraint of freedom and economic mediocrity. 
A final word on another dimension of Europe. Monnet is said to have claimed at the end of his career that if he had had the chance to start again he would have started the process of European integration with culture. To be frank: This is the dimension which is dear to all of us and where we need and want anything but centralisation. Europe's unique cultural richness is due to wide diversity. Isn't it telling that the fundament for Europe's finest achievements is, indeed, competition between innumerable people, manifold institutions and places? Does the similarity with economic success come by accident?

Another aspect would need much more attention: This is the relation of the 17 euro area countries with the other 10 members of EU not participating in EMU. There is a vast literature on different speeds of integration etc. The basic idea of such concepts was always that the «core», i.e. those countries which go ahead in integration would dominate the future. However, if this core is going in the direction of centralisation and an institutional design which is anything but fostering prosperity, then the orientation of the «outs» might change. Is this a sign that institutional competition cannot be suppressed forever? What kind of «Europe» will emerge under these conditions? The introduction of the financial transaction tax will provide a $n$ interesting test.

To conclude: I do not succumb to an obsession against European competences as opposed to national approaches. Economists have developed the concept of externalities and spillovers, identifying fields in which only common action is appropriate to develop efficient solutions. Environmental policy e.g. is such a field. My critique is, however - let me be clear-, directed against the notion that centralisation per se is the solution for Europe's internal problems and the basis for an important role in the world. And to add one last question: After so many violations of legal obligations and commitments, what is the credibility of an approach which is based on the notion that this would end in a regime of strengthened political integration?

I have not discussed the challenge of democratic legitimation and acceptance by the people which is the most important hurdle to further political integration. My intention is merely to put some question marks behind the simple battle cry «We need more Europe.» 